\title{
CDISC SDTM Lead Status Terminology
}

National Cancer Institute

\section{Source}

National Cancer Institute. CDISC SDTM Lead Status Terminology. NCI Thesaurus. Code C101867.

Terminology associated with the lead status codelist of the Clinical Data Interchange Standards Consortium (CDISC) Study Data Tabulation Model (SDT M). 